\title{
The effect of perceived barriers on social entrepreneurship intention in Malaysian universities: The moderating role of education
}

\author{
Masoumeh Shahverdi $^{\mathrm{a}}$, Kamariah Ismail ${ }^{\mathrm{b}}$ and Muhammad Imran Qureshic ${ }^{*}$
}

${ }^{a, b}$ Faculty of Management, University Technology Malaysia

${ }^{c}$ Malaysian Institute of Industrial Technology, Universiti Kuala Lumpur, Malaysia

CH R O N I C L E A B S T R A C T

Article history:

Received: November 26, 2017

Received in revised format:

March 31, 2018

Accepted: April 4, 2018

Available online:

April 5, 2018

Keywords:

Perceived barriers

Social Entrepreneurship intention

Education

Theory of planned behavior

Malaysian universities

\begin{abstract}
This paper attempts to identify barriers of social entrepreneurship intention by the moderating role of education amongst research universities in Malaysia. Entrepreneurship is regarded as the major factor for economic development while social entrepreneurship is considered as the alternative method of solving social problems. Entrepreneurship is not new for Malaysia as is evident from various policies and programs initiated by the government. However, social entrepreneurship is a relatively new phenomenon in Malaysian context that requires much attention. To promote entrepreneurship we need to know the barriers influencing on entrepreneurship to overcome the barriers and promote new policies and measures to create new ventures. The study used Ajzen's Theory of Planned Behavior as a framework to investigate the barriers of social entrepreneurship intention. Data was collected through questionnaire and confirmatory factor analysis was conducted by using AMOS 18. The multilevel sampling design was used with purposive sampling scheme in Malaysian research universities. The findings of this study show that overall students consider the lack of competency, lack of self-confidence and lack of resources were the barriers that affect social entrepreneurial intentions. Results also show that the social entrepreneurial education moderated the relationship between the perceived barriers and social entrepreneurial intentions of the students. This implies that teaching of social entrepreneurial can help to reduce perceived barriers. Also, the present study premises future directions that a cross country analysis between developing countries and between developed and developing countries can be done to figure out barriers of social entrepreneurship intention amongst students.
\end{abstract}

\section{Introduction}

It has been highlighted that social, economic and environmental aspects of development would pose the greatest challenges in the 21st (Jørgensen et al., 2009). Therefor governments are faced with many problems that they are not well equipped to deal with such rising social needs and issues (Lumpkin et al., 2013). Also, it is believed that the social entrepreneurship represents a new structure and ideology that can capture social, economic and environmental values for society's development (Nga \& Shamuganathan, 2010; Noruzi et al., 2010; Zebrowski, 2009; Davari \& Farokhmanesh, 2017). Further-

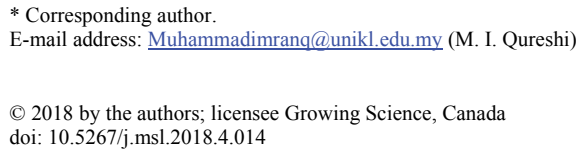


more, it is believed that social entrepreneurship provides solutions for social, economic and environmental problems through actors, individuals, and organizations acting as new pioneers (Santos, 2012; Tan \& Yoo, 2015; Verreynne et al., 2013). In this regard, the emergence of social entrepreneurs is seen as a social change agent who is creating social value (Simha \& Carey, 2012; Swanson \& Di Zhang, 2010). Intention is an integral part of any social entrepreneur's life, as he/she seeks to eliminate a social need, a social problem, and goes far beyond his/her purely commercial entrepreneurial spirit (Austin, 2006; Zahra et al., 2009). Even Mair and Marti (2006) speak about an intention formation stage, which is to some extent in line with Ajzen's (1991) theory. Students also need to have such feelings and intentions to initiate social businesses and to continue this behavior (Salamzadeh et al., 2013). Additionally, there is an increase in the creation of awareness about the importance of entrepreneurship education in academic and co-curricular activities.

In Malaysia, social entrepreneurship is in early stages and requires a proper policy to promote social entrepreneurship and its education (İlhan Ertuna \& Gurel, 2011; Kurniawan et al., 2012; Terjesen et al., 2011). Researchers have pointed out that majority of the Malaysians are not aware of the concept of social entrepreneurship and how it can benefit them, thus there is a need to understand this phenomenon in Malaysian context (Al-Mamun et al., 2012; Sarif et al., 2013; Terjesen et al., 2011). However, some educational institutions in Malaysia are involved in the promotion of social enterprises at different levels. but, some academic institution and consultancy systems in Malaysia have not yet undertaken a great deal of research and capacity development in social enterprises, hence, there is an enough room for the improvement in this area (MaGIC, 2015). To promote entrepreneurship we need to know the barriers that affect entrepreneurship intention to overcome the barriers (Yaghoubi, 2010). According to Ajzen's theory Perceived barriers are one of the factors that can affect on social entrepreneurship intention among students (Kirby \& Ibrahim, 2011; Salamzadeh et al., 2013).

Few studies have examined the differences in entrepreneurial intentions and perceived barriers to business creation among students (Giacomin et al., 2011). To accomplish this, we believe it is important to study students' perceived barriers on social entrepreneurial intention. The theme "perceived barriers" describes how young staff's self-efficacy could be negatively influenced by social exclusion, forecasted on poor academic achievement or debilitating psychological states, which may influence on their capabilities to succeed in enterprising activities (Lucas \& Cooper, 2005; Mclellan et al., 2009).

Furthermore, limited knowledge is available on the perceived barriers that reduce the social entrepreneurial intentions of the students. These barriers can be the lack of support, lack of adequate knowledge and competency, lack of self-confidence and lack of resources (Shinnar et al., 2012). Studies have already acknowledged the negative effect of these perceived barriers on social entrepreneurial intentions (Giacomin et al., 2011; Shinnar et al., 2012), but still, the role of social entrepreneurial education can play in the mitigating the effect of these barriers is unclear.

This study has used the theory of planned behavior as a theoretical framework to investigate the effect of these barriers on the social entrepreneurial intention and the moderating role of social entrepreneurial education to mitigate the effect of perceived barriers on the social entrepreneurial intentions.

\section{Literature review}

\subsection{Social entrepreneurship intention}

In the entrepreneurship literature, prior studies demonstrated the role of intentionality as the best predictor of planned behavior (Ajzen, 1991), recognizing that starting a business is an intentional act and entrepreneurship is a planned behavior (Krueger et al., 2000). Intentions reflect the motivational factors that influence behavior and are a reliable indicator of how hard a person is willing to try and how much effort he/she makes to perform a behavior (Ajzen, 1991; Austin, 2006). 
The intent is not only connected with the desire to work as an entrepreneur, but also their aspiration towards entrepreneurship (Rantanen \& Toikko, 2013). Students also need to have such feelings and intentions to initiate social businesses and to continue this behavior (Salamzadeh et al., 2013). The available literature on the entrepreneurial intentions has shown the interest of the researchers to use the theory of planned behavior to investigate the entrepreneurial intentions (Fretschner \& Weber, 2013; Mair \& Marti, 2006; Rantanen \& Toikko, 2013; Salamzadeh et al., 2013; Tan \& Yoo, 2015). This provides enough justifications to use the theory of planned behavior in the current study to investigate the social entrepreneurship intentions. Social entrepreneurship intention refers to the intention of starting a social enterprise. The literature indicates that there is a need to adapt the existing educational system if social entrepreneurs are to be encouraged (Salamzadeh et al., 2013; Yunus, 2007).

\subsection{Social Entrepreneurial education}

With the increased social problems the world is facing, there has been a demand of increased social entrepreneurship related program (Brock, 2008; Miller, 2012; Nandan \& Scott, 2013). These programs and activities are not only focusing on creating awareness and providing services for development but are also concerned with developing social entrepreneurial culture and skills (Abdou et al., 2010). In addition, for a fast developing country like Malaysia, there is an essential need of understanding the social entrepreneurship phenomenon (Sarif et al., 2013) especially when Malaysia is looking to move towards knowledge based economy (Xavier et al., 2010). Students are very crucial for developing cogent global sustainability practices and principles giving a balanced emphasis to the economic, environmental and social concerns a majority of these students will immediately contribute more to being a process of change in the delivery of public goods and social/environmental services. And they will have an important role in an economy, in particular for wealth creation (Thompson et al., 2000).

Despite the criticism, studies have shown that education influences students' inclination and behavior towards entrepreneurship (Gorman et al., 1997; Kolvereid \& Moen, 1997; Min et al., 2012). Furthermore, Tracey and Phillips (2007) highlighted that there is an increase in a number of social entrepreneurs who are enrolling in universities to learn the skills for building sustainable ventures. In this regard, It has been highlighted that universities by developing social entrepreneurship education have the opportunity of not only acting as change agents but also are in a position to develop human capital that could be used for transforming the world and addressing the social challenges (Brock \& Kim, 2011). Moreover, some articles emphasize the importance of collaborating with many partners in society when students learn to think and behave as social entrepreneurs (Jensen, 2014; Prieto, 2011). (1997) have indicated that there exist a causal relationship between education and (social) entrepreneurial behavior. Studies have suggested that higher education would influence student's intention of becoming entrepreneur (Brock, 2008; İlhan Ertuna \& Gurel, 2011; Mair \& Marti, 2006; Shankar, 2014) and local development and poverty reduction and the economic growth after they graduate, not as salary workers but as social entrepreneurs (O'Connor, 2013). While much research has focused on entrepreneurial intentions (BarNir et al., 2011; Ismail et al., 2009; Kuckertz \& Wagner, 2010; Shinnar et al., 2014; Souitaris et al., 2007), a large amount of literature concerning the social entrepreneurship education has been produced (Brock \& Steiner, 2009; Pache \& Chowdhury, 2012; Salamzadeh et al., 2013) and some research studied the effect of Social entrepreneurship education on intention (İlhan Ertuna \& Gurel, 2011; Kirby \& Ibrahim, 2011; Salamzadeh et al., 2013) but there is little study to investigate the direct effect of perceived barriers on social entrepreneurial intention, by the moderating role of Education.

\subsection{Perceived Barriers}

Perceived control of behavior is one of the dimensions of the theory of planned behavior related to the perception of an individual regarding the easiness or difficulty of a certain behavior. In fact, it proposes that a person's intention to perform the behavior will increase with his/her perceived behavioral control. This suggests that people will try to start a business if they believe they have the ability to do so and the activity is deemed to be socially acceptable (Kirby \& Ibrahim, 2011). 
Some people believe that some barriers (ex: fear of failure, irregular income, and having to work too many hours) have negative effects on student intention and these barriers should be taken into consideration when developing entrepreneurship education programs.

In this regard, previous studies conducted in the Malaysian context revealed that students lack explicit knowledge of entrepreneurship and social entrepreneurship and the intention to start their own entrepreneurial venture (MaGIC, 2015; Terjesen et al., 2011; Zakaria, 2011). Furthermore, a study referred to some problems relates social entrepreneurship programs among the Malaysian students. These problems do not have motivating students towards social entrepreneurship programs, the problem of different perceptions among the students, lack of knowledge and skills of students have also slowed down the process of social enterprise creation, lack of active involvements of government, private agencies, local and national companies in social enterprise process and lack of specialized training for the educators. Further, despite the implementation of various policies and programs by the Malaysian government to enhance entrepreneurial activity in the country, students are still lacking the awareness, confidence, abilities, and competencies required for the success of (social) entrepreneurial venture (Kurniawan et al., 2012; Terjesen et al., 2011).

Barriers to entrepreneurship can include difficulties in obtaining institutional support for aspiring social entrepreneurs, receiving family support, securing financing from lenders, building a relationship with suppliers, and/or a solid customer base. Lüthje and Franke (2003) indicate that the perceived availability of support such as access to "qualified consultants and service support for new companies" (p. 147) have positive impacts on entrepreneurial intentions. This study would expect that the perceived absence of such support may act as a barrier. Miller (2012) proposed that resource providers entrepreneurs depend on (i.e., consultants, lenders, suppliers, customers) frequently make decisions under uncertainty without access to complete information. They may, therefore, be especially vulnerable to the influence of challenges social entrepreneurs. Specifically, Onwuegbuzie and Collins (2007) found the fear of failure to be negatively related to entrepreneurial propensity. Furthermore, Miller (2012) identified the lack of knowledge and competency is another potential barrier for the social entrepreneur intentions. Additionally, Tukamushaba et al. (2011) argued that the lack of self-confidence and resources are also the potential barriers to the social entrepreneurial intentions. Moreover, According to Tukamushaba et al. (2011) the main barriers, as perceived by students who had yet to start their own venture, would appear to be the lack of awareness or information/knowledge. Of those who claimed that they would be interested in setting up a social enterprise, most indicated that they would need support/encouragement, particularly training and mentoring. However, the effect of social entrepreneurial education on social entrepreneurship intention to mitigate perceived barriers is still unclear. Thus, on the basis of above discussion study concluded following hypothesis:

H1: lack of support has a negative effect on social entrepreneurial intention.

$\mathrm{H} 2$ : lack of knowledge has a negative effect on social entrepreneurial intention.

H3: lack of competency has a negative effect on social entrepreneurial intention.

H4: lack of self-confidence has a negative effect on social entrepreneurial intention.

H5: lack of resources has a negative effect on social entrepreneurial intention.

H6: Social entrepreneurial education moderates the relationship between the perceived barriers and social entrepreneurial intention.

\section{Methodology}

\subsection{Sampling strategy}

We used multilevel sampling design with purposive sampling scheme as highlighted by Yunus (2007) that multilevel sampling involves 'sampling in all levels being purposive or sampling in all levels being random'. Purposive sampling technique is preferred for the selection of the universities. Criteria for the selection of the universities were the research universities. Research universities have more appropriate 
resources for encouraging students to be social entrepreneurial through the spinoffs and commercialization of their research opportunities. This technique is preferred as prior researchers have also used the purposive sampling technique in collecting data (Jensen, 2014; Tukamushaba et al., 2011; Yasir et al., 2013). For the analysis in the current study, students of the research universities of Malaysia were used. We collected data from 288 students from Malaysian research universities. Following sections highlights the demographic analysis using frequency tests of the respondents. Majority of the respondents belongs to age group of $18-26$ years $(55.6 \%)$. This is followed by respondents belonging to the age category of $26-30$ years $(35.2 \%)$. The rest belongs to the other age groups. Gender wise analysis indicated that majority of the respondents were female $(58.3 \%)$. The education level indicates that majority of the respondents were under graduates $(47.8 \%)$. Second highest frequency was the respondents having master's level education $(22.5 \%)$.

\subsection{Measures}

Perceived barriers are independent variable in this study. Perceived barriers refer to the degree to which students of universities consider the difficulties in starting social entrepreneurship. We used five dimensions of the independent variable of perceived barriers. These dimensions are lack of support, lack of knowledge, lack of competencies, lack of self-confidence and lack of resources. We operationalized each dimension through 3 items on five points likert scale where 1 represents strongly disagree to 5 strongly agree. The scale was adapted from Giacomin et al. (2011).

We used social entrepreneurship intention as the dependent variable. Social entrepreneurship intention refers to the intention of establishing a social enterprise. Few researches have been conducted on the phenomenon of social entrepreneurship intention (Austin, 2006; İlhan Ertuna \& Gurel, 2011; Kirby \& Ibrahim, 2011; Min et al., 2012; Prieto, Phipps, \& Friedrich, 2012; Salamzadeh et al., 2013; Tukamushaba et al., 2011). The study measured this construct on the basis of 9 items on likert scale used by Rengiah (2013).

Further, we used social entrepreneurship education as a moderator between the relationship of the perceived barriers and social entrepreneurship intention. Social entrepreneurship education refers to various programs and training conducted to inculcate the awareness and skills and abilities required to establish and successfully run a social enterprise. Numerous studies have found a direct and significant link between education and social entrepreneurship intention (Abdullah et al. 2015; Kirby \& Ibrahim, 2011; Nga \& Shamuganathan, 2010; Othman \& Ab Wahid, 2014; Pache \& Chowdhury, 2012; Salamzadeh et al., 2013). Researchers have also highlighted the linkage between social entrepreneurial traits and intentions of students to start an enterprise (Bridges, 2008; İrengün \& Arıkboğa, 2015; Mair \& Noboa, 2003; Nga \& Shamuganathan, 2010; O'Connor, Burnett, \& Hancock, 2009; Prieto, 2011) with education acting as a moderator (IIlhan Ertuna \& Gurel, 2011). For the present study, social entrepreneurship education is taken as a moderator to examine the intentions of students to start social enterprise through planned behavior theory. Social entrepreneurship education is coded dichotomously where " 0 " indicated participation in social entrepreneurship course and " 1 " refers to student who does not participate in social entrepreneurship course.

\section{Result}

\subsection{Measurement Model}

As a required step in testing the conceptual models, the suitability of the computed variables must be assessed. Confirmatory factor analysis was conducted by using AMOS 18. The results of the CFA indicated that all of the values are within the acceptable ranges as shown Fig. 1. The factor structure of each model fits the data and all fit indices met the respective criteria with $\chi 2=$ Chi-square; $\mathrm{DF}=\mathrm{Degree}$ of Freedom; $\mathrm{CMIN}=$ Minimum Chi-square; GFI= Goodness of fit index; RMR= Root Mean Square Residual; RMSEA= Root Mean Square Error of Approximation; NFI= Normed Fit Index; TLI= Tucker Lewis Index; CFI = Comparative Fit Index and AGFI= Adjusted Goodness of Fit Index. The criteria 
for eliminating the items were set on the basis of the factor loadings and the residual values of the each item. The factor loadings $>.50$ was selected to retain the items. Fig.1. showed the results of the measurement model. At the first stage, all latent constructs were correlated to test the measurement model fitness of all constructs. Model fit has been reported to $\chi 2=1130.476, \mathrm{df}=808, \mathrm{CMIN} / \mathrm{DF}=1.40$, $\mathrm{RMR}=.058, \mathrm{GFI}=.918, \mathrm{AGFI}=.848, \mathrm{TLI}=.896, \mathrm{CFI}=.915, \mathrm{RMSEA}=.057$. These values indicated a good model fit for the measurement validation through CFA.

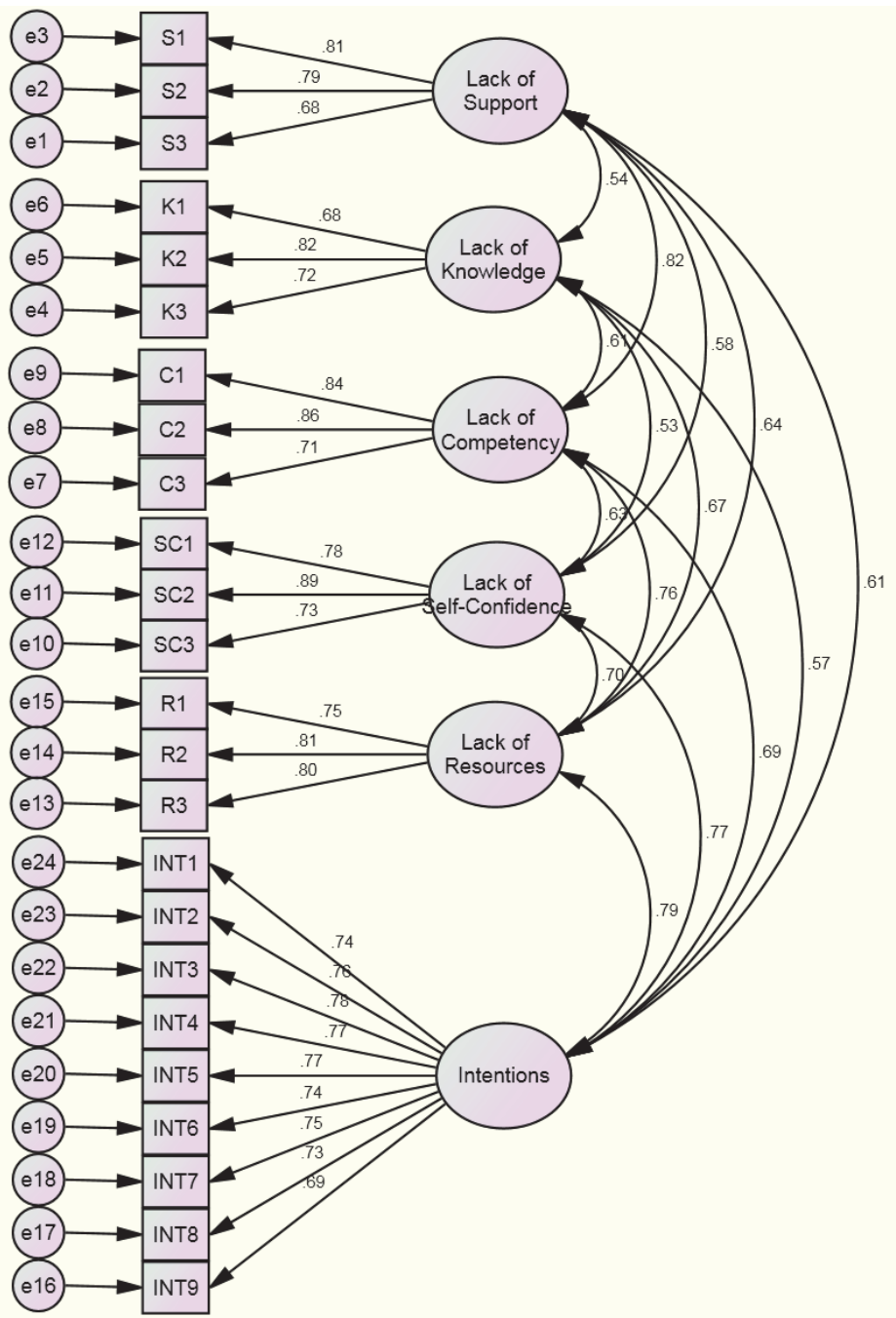

Fig.1. Measurement Model

Convergent validity is the construct indicators that reflect a large amount of the mutual proportion of variance among factors. It determines the amount of correlation among the measures of the same concept. Convergent validity deals with construct loadings, average variance extracted (AVE) and construct reliabilities. Average variance extracted is the sum of square of standardized factor loadings to represent how much variation in each item is explained by latent. The average variance extracted is the average percentage of variation explained by the measurement items in a construct. The standard value of AVE is .50 or greater. Table 1 shows the average variance extraction of each construct and results showed that all the constructs have more than .50 of average variance extraction, that shows all the constructs have sufficient amount of convergent validity. The range of Average Variation Extractions is $0.549-0.650$. The threshold value of the construct reliability is .70 or above. Table 1 shows that all the constructs have the adequate reliability of all constructs ranges from .784 to .920 . Therefore, the current study does not violate the convergent validity of the constructs. 
Discriminant validity is referred to the extent to which an instrument contains a construct that was truly distinct from all others. Discriminant validity is the degree to which similar constructs have distinct values. In this type of validity, the responses are measured without cross loading in terms of latent constructs. Discriminant validity is violated when the correlation among exogenous constructs is more than 0.85 . In discriminant validity, the value of the square root of average variance extraction should exceed than the value of inter-construct correlations. Table 1 shows the inter-construct correlations. Results indicate that all the constructs have adequate discriminant validity as the square root of average variance extracted is greater than the inter-construct correlation of each variable and also the values of inter construct are less than .85 . It means the results provide sufficient evidence of the discriminant validity of the constructs.

Table 1

Measurement model

\begin{tabular}{|c|c|c|c|c|c|c|c|c|}
\hline & CR & AVE & $\begin{array}{c}\text { Lack of } \\
\text { Resources }\end{array}$ & $\begin{array}{l}\text { Lack of } \\
\text { Support }\end{array}$ & $\begin{array}{c}\text { Lack of } \\
\text { Knowledge }\end{array}$ & $\begin{array}{c}\text { Lack of } \\
\text { Competency }\end{array}$ & $\begin{array}{c}\text { Lack of Self- } \\
\text { Confidence }\end{array}$ & Intentions \\
\hline Lack of Resources & 0.828 & 0.616 & $0.785^{*}$ & & & & & \\
\hline Lack of Support & 0.806 & 0.582 & 0.644 & $0.763 *$ & & & & \\
\hline Lack of Knowledge & 0.784 & 0.549 & 0.670 & 0.536 & $0.741 *$ & & & \\
\hline Lack of Competency & 0.847 & 0.650 & 0.762 & 0.620 & 0.607 & $0.806^{*}$ & & \\
\hline Lack of Self-Confidence & 0.844 & 0.644 & 0.696 & 0.584 & 0.527 & 0.634 & $0.803 *$ & \\
\hline Intentions & 0.920 & 0.560 & 0.769 & 0.606 & 0.567 & 0.694 & 0.719 & $0.749 *$ \\
\hline
\end{tabular}

*Square root of AVE

\subsection{Structural Model}

The proposed structural model consists of 5 hypotheses, as indicated in Fig. 1. Our first hypothesis states that H1: lack of support has a negative effect on social entrepreneurial intention. So the standardized path coefficient of lack of support and social entrepreneurial intention was 0.01 with p value above than 0.05 . Thus hypothesis 1 was not supported and the study does not establish a relationship between the lack of support and social entrepreneurial intention.

Our second hypothesis states that H2: lack of knowledge has a negative effect on social entrepreneurial intention. So the standardized path coefficient of lack of knowledge and social entrepreneurial intention was 0.00 with $p$ value above than 0.05 . Thus hypothesis 2 was not supported and study does not establish relationship between the lack of knowledge and social entrepreneurial intention.

Our third hypothesis states that H3: lack of competency has negative effect on social entrepreneurial intention. The standardized path coefficient of lack of competency and social entrepreneurial intention was -0.11 with $p$ value less than 0.05 . Thus hypothesis 3 was supported and study establishes negative relationship between the lack of competency and social entrepreneurial intention.

Our fourth hypothesis states that H4: lack of self-confidence has negative effect on social entrepreneurial intention. The standardized path coefficient of lack of self-confidence and social entrepreneurial intention was -0.40 with $p$ value less than 0.05 . Thus hypothesis 4 was supported and study establishes negative relationship between the lack of self-confidence and social entrepreneurial intention.

Our fifth hypothesis states that H5: lack of resources has negative effect on social entrepreneurial intention. The standardized path coefficient of lack of resources and social entrepreneurial intention was -0.42 with $p$ value less than 0.05 . Thus hypothesis 5 was supported and study establishes negative relationship between the lack of resources and social entrepreneurial intention. Fig. 2 shows the direct relationship 


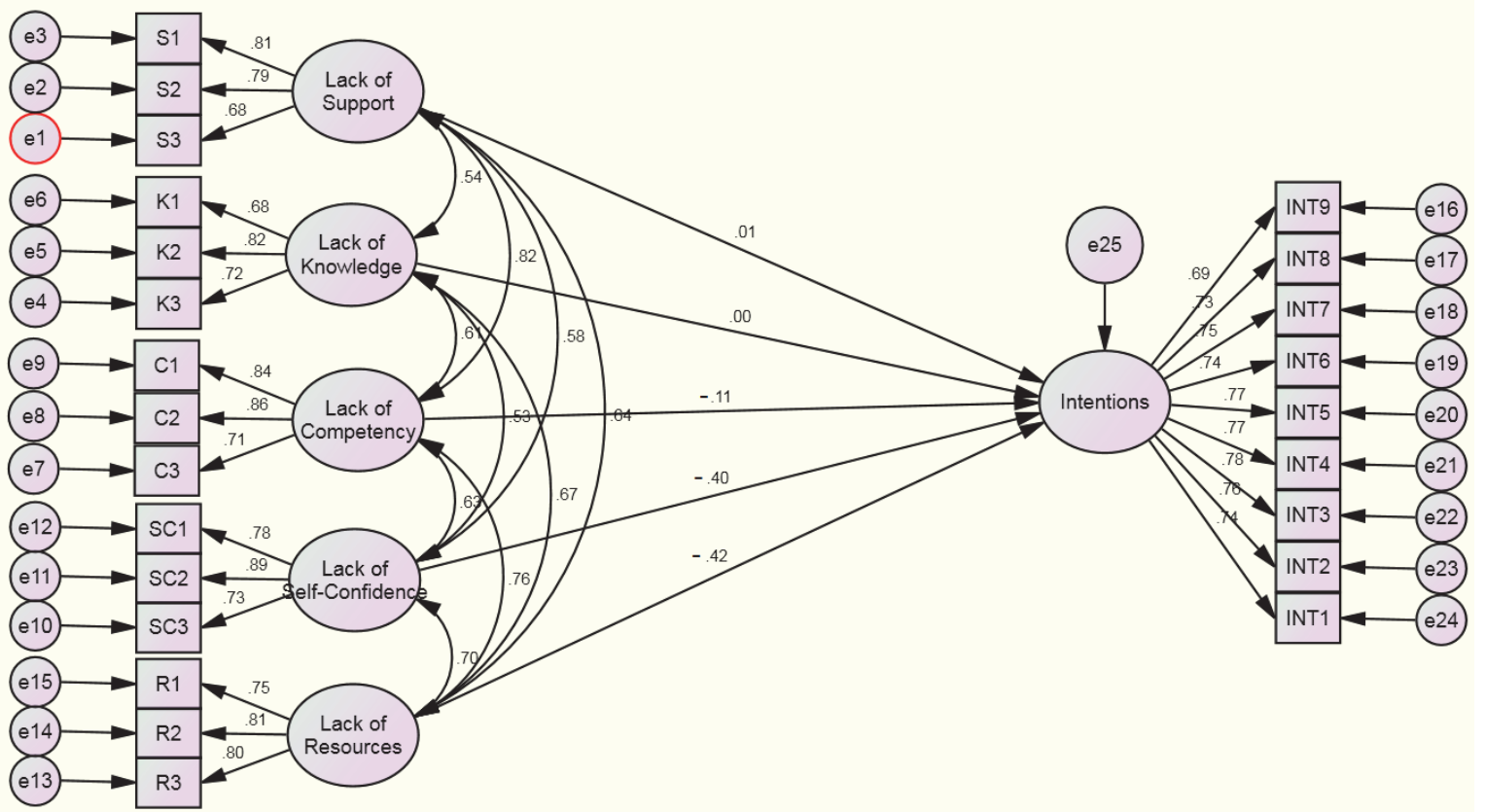

Fig. 2. Structural Model 1

We used group analysis to test the moderation effect of social entrepreneurial education between the relationship of perceived barriers and social entrepreneurial intentions. For this purpose, study runs two models on the two different respondents groups. First group was the students who have already taken the social entrepreneurial course during their studies and the second group included those students who did not take social entrepreneurial course during their studies. The difference in the Chi-Square of both models tells the moderation effect of the social entrepreneurial education. Results of the group analysis were mentioned in the Table 2.

Table 2

The results of group analysis for the social entrepreneurial education

\begin{tabular}{lcc}
\hline \multicolumn{1}{c}{ Relationships } & $\begin{array}{c}\text { Model 1 (Educated) } \\
\text { Path coefficient }\end{array}$ & $\begin{array}{c}\text { Model 2 (Non- Educated) } \\
\text { Path coefficient }\end{array}$ \\
\hline Lack of support $\rightarrow$ Intentions & 0.05 & 0.03 \\
Lack of knowledge $\rightarrow$ Intentions & 0.03 & $0.21^{* *}$ \\
Lack of competency $\rightarrow$ Intentions & $0.21^{* *}$ & $0.13^{* *}$ \\
Lack of self-confidence $\rightarrow$ Intentions & $0.42^{* *}$ & $0.40^{* *}$ \\
Lack of resources $\rightarrow$ Intentions & $0.51^{* *}$ & $0.41^{* *}$ \\
\hline
\end{tabular}

Table 2 shows the difference in results between both groups. Hypothesis 1 was not supported by two groups. It means that lack of support has a negative effect on social entrepreneurial intention was not supported by a student who educated and non-educated on social entrepreneurship. Hypothesis 2 was not supported by the students who took the social entrepreneurial course during their studies. This means the students who have passed the social entrepreneurial course do not perceive lack of knowledge as a barrier for entering in social entrepreneurial activities in future. However, the lack of knowledge affect negatively to the social entrepreneurial intentions was supported by the students who did not take the social entrepreneurial course during their studies. Hypothesis 3 was supported by two groups. It means that lack of competency has a negative effect on social entrepreneurial intention by educated students and non-educated ones on social entrepreneurship. Hypothesis 4 was supported by two groups. It means that lack of self-confidence has negative effect on social entrepreneurial intention by educated students and non-educated ones on social entrepreneurship. Hypothesis 5 was supported by two groups. It means that lack of resources has negative effect on social entrepreneurial intention 
by educated students and non-educated ones on social entrepreneurship. Chi-square difference test was applied to test the significance of the moderation effect. Table 3 shows the results of the Chi-square difference test for both models.

Table 3

The summary of moderation effect (Social entrepreneurial education)

\begin{tabular}{|c|c|c|}
\hline Model & Chi Square & DF \\
\hline Overall & 1347.9 & 347 \\
\hline Educated & 891 & 241 \\
\hline Non Educated & 561 & 199 \\
\hline Change & 330 & 42 \\
\hline t value & \multicolumn{2}{|c|}{7.86} \\
\hline Significance & \multicolumn{2}{|c|}{0.000} \\
\hline
\end{tabular}

Chi-square value for the model on the data of the students who took the social entrepreneurial course during their studies was 891, with 241 degrees of freedom and for the non-educated group was 561 with degrees of freedom 199. The difference between the Chi-square was 330 with 42 degrees of freedom. T value for the test was 7.86 (must be above 1.96) with the $p$ value of 0.000 (regression: must be less than 0.05). This indicates the existence of moderation effect of social entrepreneurship education between the relationship of the perceived barriers and social entrepreneurial intentions.

\section{Discussion and conclusion}

The aim of this study was to investigate the relationship between the five perceived barriers with the social entrepreneurial intention of the students in Malaysian Research University along with moderation effect of social entrepreneurial education. We have considered the five types of the perceived barriers; namely lack of support, lack of knowledge, lack of competency, lack of self-confidence and lack of resources. The results indicated that overall students considered the lack of competency, lack of self-confidence and lack of resources as the barriers influencing on the social entrepreneurial intentions of the research university students in Malaysia. However, the lack support and lack of knowledge were not considered as the potential barriers for the social entrepreneurial intentions of the students. Results also indicated that the social entrepreneurial education moderates the relationship between the perceived barriers and social entrepreneurial intentions of the students. The students who passed the social entrepreneurial course during their graduation are less likely to vulnerable to the perceived barriers to enter social entrepreneurial activities in future as compared to those who did not attend social entrepreneurship programs as a course during their study period. This implies that teaching of social entrepreneurial course at the university level can help to reduce perceived barriers that may reduce the entrepreneurial intentions of the university students. Thus, the Malaysian government in order to enhance the social entrepreneurial activities in the country could strategize the teaching of social entrepreneurial course as a compulsory subject at university level to reduce the perceived barriers among university students in Malaysia. This study recommends that a cross country study among developing countries and developed and developing countries to realize barriers of social entrepreneurship intention in universities.

\section{References}

Abdou, E., Fahmy, A., Greenwald, D., \& Nelson, J. (2010). Social entrepreneurship in the Middle East. Toward Sustainable.

Abdullah, J., Johari, H. S. Y., Bakri, A. A., \& Razak, W. M. W. A. (2015). Students and Women Entrepreneurs' Collaborations in Social Entreprise Program at UiTM, Malaysia. Procedia-Social and Behavioral Sciences, 168, 97-103.

Ajzen, I. (1991). The theory of planned behavior. Organizational behavior and human decision processes, 50(2), 179-211. 
Al-Mamun, A., Malarvizhi, C., Hossain, S., \& Tan, S.-H. (2012). Examining the effect of microcredit on poverty in Malaysia. ASEAN Economic Bulletin, 29(1), 15-28.

Austin, J. E. (2006). Three avenues for social entrepreneurship research. In Social entrepreneurship (pp. 22-33): Springer.

BarNir, A., Watson, W. E., \& Hutchins, H. M. (2011). Mediation and moderated mediation in the relationship among role models, self-efficacy, entrepreneurial career intention, and gender. Journal of Applied Social Psychology, 41(2), 270-297.

Bridges, C. M. (2008). Entrepreneurship education and economic development: preparing the workforce for the twenty-first century economy. Clemson University,

Brock, D. D. (2008). Social Entrepreneurship: Using the New Millennium Development Goals to Make an Impact on Society.

Brock, D. D., \& Kim, M. (2011). Social entrepreneurship education resource handbook.

Brock, D. D., \& Steiner, S. (2009). Social entrepreneurship education: Is it achieving the desired aims?

Davari, A., \& Farokhmanesh, T. (2017). Impact of entrepreneurship policies on opportunity to startup. Management Science Letters, 7(9), 431-438.

Fretschner, M., \& Weber, S. (2013). Measuring and understanding the effects of entrepreneurial awareness education. Journal of Small Business Management, 51(3), 410-428.

Giacomin, O., Janssen, F., Pruett, M., Shinnar, R. S., Llopis, F., \& Toney, B. (2011). Entrepreneurial intentions, motivations and barriers: Differences among American, Asian and European students. International Entrepreneurship and Management Journal, 7(2), 219-238.

Gorman, G., Hanlon, D., \& King, W. (1997). Some research perspectives on entrepreneurship education, enterprise education and education for small business management: a ten-year literature review. International Small Business Journal, 15(3), 56-77.

İlhan Ertuna, Z., \& Gurel, E. (2011). The moderating role of higher education on entrepreneurship. Education + Training, 53(5), 387-402.

İrengün, O., \& Arıkboğa, Ş. (2015). The Effect of Personality Traits on Social Entrepreneurship Intentions: A Field Research. Procedia-Social and Behavioral Sciences, 195, 1186-1195.

Ismail, M., Khalid, S. A., Othman, M., Jusoff, H. K., Rahman, N. A., Kassim, K. M., \& Zain, R. S. (2009). Entrepreneurial intention among Malaysian undergraduates. International Journal of Business and Management, 4(10), 54.

Jensen, T. L. (2014). A holistic person perspective in measuring entrepreneurship education impactSocial entrepreneurship education at the Humanities. The International Journal of Management Education, 12(3), 349-364.

Jørgensen, M. S., Jørgensen, U., \& Clausen, C. (2009). The social shaping approach to technology foresight. Futures, 41(2), 80-86.

Kirby, D. A., \& Ibrahim, N. (2011). The case for (social) entrepreneurship education in Egyptian universities. Education + Training, 53(5), 403-415.

Kolvereid, L., \& Moen, Ø. (1997). Entrepreneurship among business graduates: does a major in entrepreneurship make a difference? Journal of European Industrial Training, 21(4), 154-160.

Krueger, N. F., Reilly, M. D., \& Carsrud, A. L. (2000). Competing models of entrepreneurial intentions. Journal of Business Venturing, 15(5), 411-432.

Kuckertz, A., \& Wagner, M. (2010). The influence of sustainability orientation on entrepreneurial intentions-Investigating the role of business experience. Journal of Business Venturing, 25(5), 524-539.

Kurniawan, Y., Abdullah, W. M. W., Yusuff, N. A., \& Zakaria, F. (2012). Social entrepreneurship as medium to growing economy of communities.

Langowitz, N., \& Minniti, M. (2007). The entrepreneurial propensity of women. Entrepreneurship Theory and Practice, 31(3), 341-364.

Lucas, W., \& Cooper, S. Y. (2005). Measuring entrepreneurial self-efficacy. Paper presented at the EDGE conference: bridging the gap: entrepreneurship in theory and practice, Singapore.

Lumpkin, G., Moss, T. W., Gras, D. M., Kato, S., \& Amezcua, A. S. (2013). Entrepreneurial processes in social contexts: how are they different, if at all?. Small Business Economics, 40(3), 761-783. 
Lüthje, C., \& Franke, N. (2003). The 'making' of an entrepreneur: testing a model of entrepreneurial intent among engineering students at MIT. R\&D Management, 33(2), 135-147.

MaGIC. (2015). Blueprint 2015-2018. Unleashing the power of social entrepreneurship, Malaysian Social Entrepreneurship Blueprint.

Mair, J., \& Marti, I. (2006). Social entrepreneurship research: A source of explanation, prediction, and delight. Journal of World Business, 41(1), 36-44.

Mair, J., \& Noboa, E. (2003). Social entrepreneurship: How intentions to create a social enterprise get formed.

Mclellan, R., Barakat, S., \& Winfield, S. (2009). The Impact of Entrepreneurial Programmes: Lessons from examining self-efficacy. Paper presented at the 32nd Institute for Small Business and Entrepreneurship Conference.

Miller, T. L. (2012). Educating the Minds of Caring Hearts: Comparing the Views of Practitioners and Educators on the Importance of Social Entrepreneurship Competencies. Academy oi Management Learning \& Education, 11(3), 349-370.

Min, R. S., Ling, K. C., \& Hooi, K. K. (2012). A study of entrepreneurial intention among Malaysian tertiary students. Paper presented at the International Conference of Management, Economics and Finance (ICMEG 2012), Kuching, Sawarak, Malaysia.

Nandan, M., \& Scott, P. A. (2013). Social entrepreneurship and social work: the need for a transdisciplinary educational model. Administration in Social work, 37(3), 257-271.

Nga, J. K. H., \& Shamuganathan, G. (2010). The influence of personality traits and demographic factors on social entrepreneurship start up intentions. Journal of Business Ethics, 95(2), 259-282.

Noruzi, M. R., Westover, J. H., \& Rahimi, G. R. (2010). An exploration of social entrepreneurship in the entrepreneurship era. Asian Social Science, 6(6), 3.

O'Connor, A. (2013). A conceptual framework for entrepreneurship education policy: Meeting government and economic purposes. Journal of Business Venturing, 28(4), 546-563.

O'Connor, A., Burnett, H., \& Hancock, G. (2009). Converging entrepreneurship education with business incubation: An exploration of the development process for entrepreneurs.

Onwuegbuzie, A. J., \& Collins, K. M. (2007). A typology of mixed methods sampling designs in social science research. The Qualitative Report, 12(2), 281-316.

Othman, N., \& Ab Wahid, H. (2014). Social entrepreneurship among participants in the students in free enterprise program. Education+ Training, 56(8/9), 852-869.

Pache, A.-C., \& Chowdhury, I. (2012). Social entrepreneurs as institutionally embedded entrepreneurs: Toward a new model of social entrepreneurship education. Academy of Management Learning \& Education, 11(3), 494-510.

Prieto, L. C. (2011). The Influence Of Proactive Personality On Social Entrepreneurial Intentions: The Moderating Role Of Hope. Paper presented at the Allied Academies International Conference. Academy of Entrepreneurship. Proceedings.

Prieto, L. C., Phipps, S. T., \& Friedrich, T. L. (2012). Social entrepreneur development: An integration of critical pedagogy, the theory of planned behavior and the ACS model. Academy of Entrepreneurship Journal, 18(2), 1.

Rantanen, T., \& Toikko, T. (2013). Social values, societal entrepreneurship attitudes and entrepreneurial intention of young people in the Finnish welfare state. The Poznan University of Economics Review, 13(1), 7.

Rengiah, P. (2013). Effectiveness of entrepreneurship education in developing entrepreneurial intentions among Malaysian university students.

Salamzadeh, A., Azimi, M. A., \& Kirby, D. A. (2013). Social entrepreneurship education in higher education: insights from a developing country. International Journal of Entrepreneurship and Small Business, 20(1), 17-34.

Santos, F. M. (2012). A positive theory of social entrepreneurship. Journal of Business Ethics, 111(3), 335-351.

Sarif, S. M., Sarwar, A., \& Ismail, Y. (2013). Practice of social entrepreneurship among the Muslim entrepreneurs in Malaysia. Middle East Journal of Scientific Research, 14(11), 1463-1470. 
Shankar, N. (2014). Effect of Social Factors, Entrepreneurial Behavior towards Entrepreneurial Intention Among Law Graduates. International Journal of Management Research and Reviews, 4(2), 215.

Shinnar, R. S., Giacomin, O., \& Janssen, F. (2012). Entrepreneurial perceptions and intentions: The role of gender and culture. Entrepreneurship Theory and Practice, 36(3), 465-493.

Shinnar, R. S., Hsu, D. K., \& Powell, B. C. (2014). Self-efficacy, entrepreneurial intentions, and gender: Assessing the impact of entrepreneurship education longitudinally. The International Journal of Management Education, 12(3), 561-570.

Simha, A., \& Carey, M. R. (2012). The encyclical letter (Caritas in Veritate) -A shout-out to social entrepreneurship? The Journal of Entrepreneurship, 21(1), 1-23.

Souitaris, V., Zerbinati, S., \& Al-Laham, A. (2007). Do entrepreneurship programmes raise entrepreneurial intention of science and engineering students? The effect of learning, inspiration and resources. Journal of Business Venturing, 22(4), 566-591.

Swanson, L. A., \& Di Zhang, D. (2010). The social entrepreneurship zone. Journal of Nonprofit \& Public Sector Marketing, 22(2), 71-88.

Tan, W.-L., \& Yoo, S.-J. (2015). Social Entrepreneurship Intentions of Nonprofit Organizations. Journal of Social Entrepreneurship, 6(1), 103-125.

Terjesen, S., Lepoutre, J., Justo, R., \& Bosma, N. (2011). Global Entrepreneurship Monitor report on social entrepreneurship. Global Entrepreneurship Research Association (GERA). Babson College, Babson Park, MA, United States.

Thompson, J., Alvy, G., \& Lees, A. (2000). Social entrepreneurship-a new look at the people and the potential. Management Decision, 38(5), 328-338.

Tracey, P., \& Phillips, N. (2007). The distinctive challenge of educating social entrepreneurs: A postscript and rejoinder to the special issue on entrepreneurship education. Academy of Management Learning \& Education, 6(2), 264-271.

Tukamushaba, E. K., Orobia, L., \& George, B. P. (2011). Development of a conceptual model to understand international social entrepreneurship and its application in the Ugandan context. Journal of International Entrepreneurship, 9(4), 282-298.

Verreynne, M.-L., Miles, M. P., \& Harris, C. (2013). A short note on entrepreneurship as method: a social enterprise perspective. International Entrepreneurship and Management Journal, 9(1), 113128.

Xavier, R., Ayob, N., Nor, L. M., \& Yusof, M. (2010). Entrepreneurship in Malaysia. The Global Entrepreneurship Monitor (GEM) Malaysian Report, 2010. Global Entrepreneurship Research Consortium (GERA).

Yaghoubi, J. (2010). Study barriers to entrepreneurship promotion in agriculture higher education. Procedia-Social and Behavioral Sciences, 2(2), 1901-1905.

Yasir, M., Imran, R., \& Irshad, M. K. (2013). Mediating Role Of Organizational Climate In The Relationship Between Transformational Leadership, Its Facets And Organizational Performance. Actual Problems of Economics/Aktual'ni Problemi Ekonomiki, 145(7), 559-569.

Yunus, M. (2007). Creating a world without poverty: Social business and the future of capitalism: Public Affairs.

Zahra, S. A., Gedajlovic, E., Neubaum, D. O., \& Shulman, J. M. (2009). A typology of social entrepreneurs: Motives, search processes and ethical challenges. Journal of Business Venturing, 24(5), 519-532.

Zakaria, F. (2011). Social enterprise in Malaysia: The UMK experience.

Zebrowski, C. R. (2009). Governing the network society: a biopolitical critique of resilience.

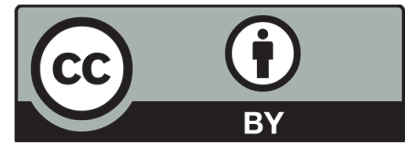

(C) 2018 by the authors; licensee Growing Science, Canada. This is an open access article distributed under the terms and conditions of the Creative Commons Attribution (CC-BY) license (http://creativecommons.org/licenses/by/4.0/). 